Darka

Podmenik

\title{
USPEŠNO VKLJUČEVANJE V SOCIALNO OKOLJE
}

\section{Primeri "dobre prakse"}

Namen prispevka je predstavitev "aktivnih" državljanov in državljank kot primera uspešnega vključevanja posameznikov $\mathrm{v}$ družbeno okolje $\mathrm{z}$ delovanjem in učenjem. $\mathrm{V}$ prispevku navedeni podatki in primeri so bili obdelani v okviru mednarodnega raziskovalnega projekta Education and Training for Governance and Active Citizenship in Europe (ETGACE). V projekt je poleg Slovenije vključenih še pet zahodnoevropskih držav. ${ }^{1}$ Osrednji raziskovalni cilj projekta je bil proučevanje procesov učenja "aktivnih" državljanov/državljank in oblikovanje zaključkov o možnostih in načinih izobraževanja odraslih. Ugotovitve projekta med drugim kažejo, da so za uspešno delovanje in učenje "aktivnih" državljanov in državljank pomembne tako osebnostne karakteristike kot tudi responzivno socialno okolje. V nadaljevanju prispevka se bom osredotočila na odnos med aktivnimi posamezniki in okoljem, še posebej $\mathrm{v}$ času tranzicije, in kot dokumentacijo predstavila dva primera uspešnega vključevanja v "tranzicijsko" okolje.

Okolje, ki se nosilcem delovanja vselej kaže kot obstoječa ali potencialno mogoča (institucionalna) struktura, je po Giddensu prav tako dinamična resničnost, kot so to delujoče prakse akterjev. Družbene strukture ne obstajajo samostojno in neodvisno tako v sintagmatski kot tudi ne v paradigmatični dimenziji. To pomeni, da same po sebi ne oblikujejo družbenih odnosov in ne reproducirajo družbenih praks, prav tako kot tudi družbeno delovanje ni izključno določujoče za oblikovanje družbenih struktur. Družbene strukture
$\mathrm{Z}$ aktivnim vključevanjem $\mathrm{v}$ socialno okolje razumemo tiste interakeije med posamezniki in/ali skupinami ter socialnim okoljem, ki ne potekajo $\mathrm{v}$ obliki pasivnega prilagajanja, pač pa vodijo $\mathrm{k}$ spremembam tako delujočih posameznikov in skupin kot tudi socialnega okolja. Teoretični koncept, s katerim je mogoče podpreti takšno obliko dvostransko "spreminjajoče" interakcije med delujočimi oziroma akterji in socialnim okoljem, je Giddensova teorija dualnosti (družbenih) struktur.

so v medsebojnem odnosu z družbenim delovanjem in njegovimi nosilci; so hkrati posrednik, preko katerega delovanje poteka, rezultat delujočih družbenih praks in dejavnik, ki vpliva na potek delovanj.

$\mathrm{Z}$ vidika razvoja loči Giddens med tradicionalnimi in (post)modernimi družbami. V drugih delovanje presega časovne in prostorske (nacionalno-državne) okvire kot tudi kulturne kontekste. Družbeno delovanje v (post)modernih družbah ni zamejeno s tradicionalnimi ovirami, kot so zgodovinski vzor$\mathrm{ci}$, rituali in rutine. $\mathrm{V}$ neomejenem prostoru in času takšno delovanje omogoča posredovanje novih družbenih praks in znanj. (M. O'Brien, 1998, 13)

Če se $\mathrm{z}$ vidika tega skiciranega povzetka Giddensove razlage strukturacije ozremo na slovensko družbo $\mathrm{v}$ času sistemskih sprememb, je oblikovanje demokratične slovenske družbe in države mogoče videti ne le 


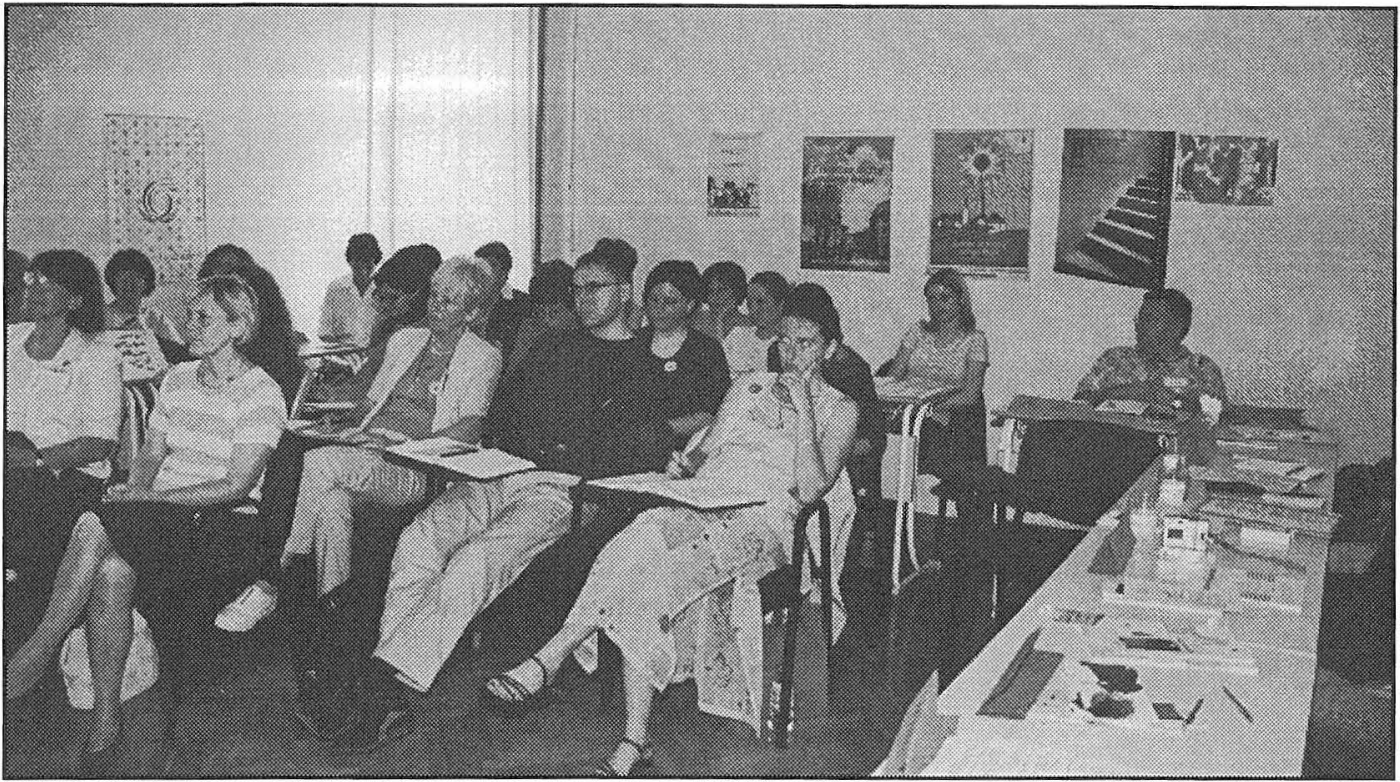

kot obsežno prestrukturacijo družbenih struktur (nove demokratične institucije), pač pa tudi kot vzporedno uveljavitev novih družbenih praks, praviloma $\mathrm{v}$ smeri detradicionalizacije in globalizacije.

$\mathrm{V}$ kontekstu uvodne definicije soodvisnosti družbenih struktur in nosilcev družbenih iniciativ in aktivnosti je mogoč sklep, da so tako uvedba novih demokratičnih institucij kot tudi nove družbene prakse odprle cel spekter možnosti za aktiviranje posameznikov in $\mathrm{s}$ tem za njihov aktiven vstop v družbeno okolje. Proučevanje vzorca slovenskih "aktivnih" državljanov in državljank je pokazalo, da je obdobje tranzicije sovpadalo s specifičnimi oblikami "aktivnega" državljanstva.

\section{"AKTIVNI" DRŽAVLJANI IN DRŽAVLJANKE - VKLJUČEVANJE V OKOLJE Z DELOVANJEM IN UČENJEM}

Definicija "aktivnega" državljana, državljanke, ki jo bom povzela po definiciji iz projekta ETGACE2 $^{2}$, je širša od klasičnih definicij državljanov in državljanstva. Aktivni državljani, državljanke so osebe, ki so dejavne v javnosti; s svojo dejavnostjo prispevajo $\mathrm{k}$ "splošnemu dobremu" - torej ne uresničujejo le osebnih, individualnih interesov - in delujejo v korist splošno priznanih demokratičnih ciljev in vrednot. Ko primerjamo definiciji "aktivnega" državljanstva in klasično definicijo državljanske participacije (v obstoječih demokratičnih institucijah - na volitvah in referendumih, $v$ političnih strankah in organizacijah), vidimo, da je "aktivno" državljanstvo opredeljeno širše. "Aktivni" državljani in državljanke delujejo skoraj na vseh družbenih področjih (na področju dela, civilne družbe in na zasebnem področju) na različne načine, kar omogoča uvajanje sprememb in inovacij. Poudarek na inovacijah in spremembah pa vključuje v definicijo "aktivnega" državljanstva tudi proces učenja; inovativno delovanje je hkrati učenje. In obratno, učenje v kontekstu "aktivnega" državljanstva poteka kot "učenje z delovanjem". Kot so pokazali rezultati projekta, je aktivno državljanstvo nenehen proces učenja, na katerega vplivajo tako individualne karakteristike posameznikov kot tudi tekoče spremembe v socialnem okolju, na lokalnih, regionalnih, nacionalnih in globalnih ravneh. 
Naj omenim nekaj ključnih individualnih dejavnikov, ki vplivajo na delovanje in učenje aktivnih državljanov in državljank: oseb-

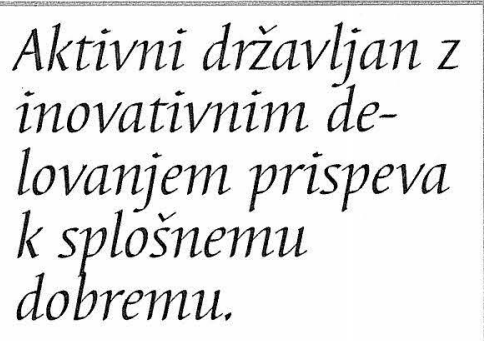

nostna motivacija, družinski izvor in okolje, pomembni "drugi", primarne skupine, identifikacija s skupinami iz socialnega okolja, razvijanje sposobnosti za kritično reflektiranje, interpretiranje in reagiranje na socialne situacije, zavezanost in predanost ciljem ter skupinam in nenehno izpopolnjevanje osebnih znanj ter veščin $\mathrm{v}$ procesu učenja.

$\mathrm{V}$ interakciji s socialnim okoljem je za aktivne državljane in državljanke pomembno primerno odzivanje na izzive iz okolja in vključenost ter obvladovanje socialnih omrežij.

Aktivno državljanstvo je izgradnja individualnih identitet na osnovi osebnih motivov, izzivov iz okolja, povezav in sodelovanja. Hkrati pa oblikovanje odgovornosti do "samih sebe", do dejavnosti, katerih nosilei so aktivni državljani/ državljanke, in do drugih, $z$ namenom doseganja učinkovitosti, tako individualne kot v korist "drugih". Aktivno državljanstvo pa je tudi nenehno tučenje $\mathrm{z}$ odzivanjem na izzive, ki izhajajo tako iz osebnih izkušenj kot tudi iz socialnega okolja.

\section{VZPODBUDNO OKOLJE V ČASU TRANZICIJE}

Za aktiviranje in delovanje posameznikov sta pomembni dve vrsti dejavnikov: individualni in družbeni. Prvi kot prirojene in pridobljene lastnosti, ki posameznike navajajo na inovativne individualne prakse, in drugi kot lastnosti strukturirajočega okolja, ki omogoča prevajanje individualnih praks $\mathrm{v}$ socialne. $\mathrm{V}$ času tranzicije je, gledano $\mathrm{z}$ vidika nosilcev individualnih praks, družbeno okolje responzivno, kar pomeni, da sta prevodljivost in dovzetnost družbenega okolja za individualne pobude, dejavnosti in inovacije večji. To je v veliki meri mogoče pripisati oblikovanju novih družbenih pravil in institucij.

$\mathrm{V}$ tem kontekstu je mogoče razložiti rezultate analize biografskih intervjujev $\mathrm{v}$ projektu ETGACE, ki so med drugim pokazali, da aktivni državljani in državljanke iz slovenskega vzorca - $\mathrm{v}$ primerjavi $\mathrm{s}$ posamezniki in posameznicami iz vzorcev petih zahodnih evropskih držav - izstopajo tako po inovativnosti kot po učinkovitosti. V spodnji preglednici, ki kaže vključenosti in premike aktivnih državljanov in državljank iz slovenskega vzorca v socialno okolje pred in po osamosvojitvi Slovenije, je učinkovitost mogoče razbrati iz vključenosti izbranih akterjev $v$ različne institucije in področja ter iz premikov na vodstvene položaje, inovativnost pa iz ustanovitve novih institucij. Razen aktivne državljanke in dveh državljanov, ki sta bila pred osamosvojitvijo še premlada za aktivno državljanstvo (Bor in Leo), so se v preglednici predstavljeni aktivni državljani in državljanke opazno "aktivirali" ob prehodu iz "starega" v "novi", demokratični sistem. Čeprav tudi v prejšnjem sistemu niso bili pasivni; skoraj vsi so bili redno zaposleni, dobra polovica jih je bila vključenih tudi $\mathrm{v}$ civilno družbene in politične organizacije. Vendar kot jih je večina povedala $v$ intervjujih, je bilo njihovo delovanje izven strokovnega področja omejeno, pri nekaterih celo povsem pasivizirano (gl. spodnji del preglednice z naslovom "Pred tranzicijo"). Primerjava aktivnosti in položajev posameznikov in posameznic $\mathrm{v}$ spodnjem delu preglednice $\mathrm{s}$ tistimi iz zgornjega dela preglednice ( $\mathrm{z}$ naslovom "V času tranzicije") nazorno kaže premike. Nekateri so svoje delovanje razširili na več področij, drugi so se aktivirali na vodstvenih položajih, polovica pa jih je ustanovila ali bila soustanovitelj/soustanoviteljica novih institucij. 


\section{SOCIALNO-STRUIKTURALNI \\ PREMIKI: VKLJUČENOST AKTTVINIH \\ DRŽAVLJANOV IN DRŽAVLJANK IZ \\ SLOVENSKEGA VZORCA V \\ SOCIALNO OKOLJE PRED IN PO \\ UVEDBI DEMOKRATIČNIH \\ [NSTITUCI] $^{3}$}

Pred spremembo sistema je kar nekaj posameznikov in posameznic delovalo $\mathrm{v}$ okvirih, ki so bili ožji od njihovih zmožnosti in sposobnosti, v nekaterih primerih zaradi "nepravih" političnih ali verskih prepričanj. V času sprememb v socialnem okolju so postali nosilci/nosilke novih iniciativ in (so)organizatorji/organizatorice novih političnih in civilno družbenih organizacij in institucij.

Nekaj jih je pokazalo visoko stopnjo iniciativnosti, sposobnosti in seveda tudi znanj ob nastajanju zasebnih podjetij. Nekaj jih je bilo izvoljenih $\mathrm{v}$ politične institucije. Skoraj vsem pa je skupno, da so veliko znanj in spretnosti pridobili $\mathrm{v}$ predtranzicijskem času. Pri tem ne gre le za formalno pridoblje-

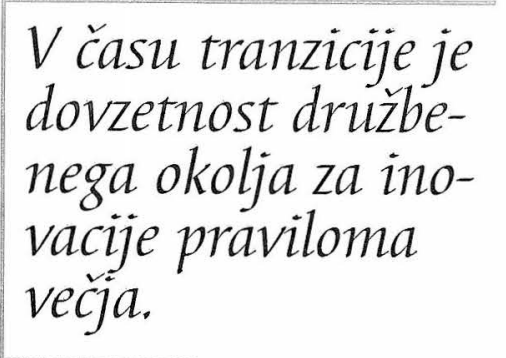
dovzetnost druzbenega okolja za inovacije praviloma večja. na znanja, ki jih intervjuvanci/intervjuvanke le redko omenjajo $\mathrm{v}$ svojih biografskih zgodbah, pač pa za znanja in veščine, ki so jih pridobili $\mathrm{z}$ vključenostjo $\mathrm{v}$ delovne, politične in druge organizacije.

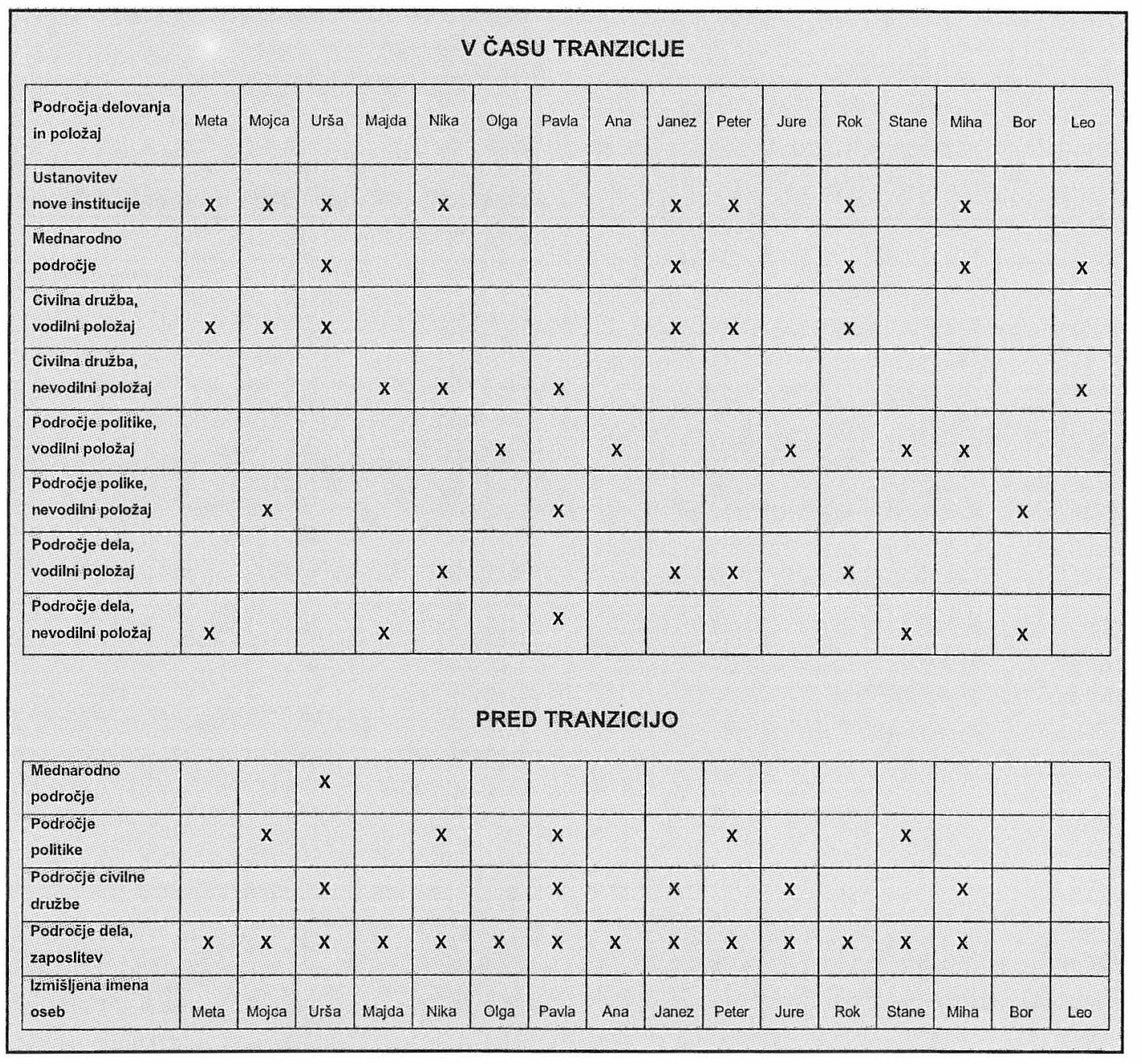




\section{PRIMERI "DOBRIH PRAKS" UČENJA IN DELOVANJA}

"Dobre prakse" so primeri, ali še bolje, zgledi, ki sem jih izbrala iz opisov delovanja in učenja posameznikov in posameznic, ki so $\mathrm{s}$ svojimi "življenjskimi zgodbami" sodelovali pri raziskavi. Pri oznaki in izboru "dobre prakse" se je smiselno izogniti razumevanju "dobrega" kot prilastka aktivnega državljanstva. Aktivno državljanstvo kot politična praksa oziroma delovanje (pojem, ki ga uvaja H. Arendt) namreč po definiciji izključuje tako imenovana dobra dela. Ne le Arendt, ampak vrsta avtorjev, ki jih navaja, izključujejo dobroto in delovanje iz dobrote ne le iz političnega, pač pa tudi iz (modernega) javnega prostora ${ }^{4}$ Atribut "dobre" pri praksah udeležencev in udeleženk $v$ raziskavi gre torej razumeti v kontekstu vprašanja 'dobre za kaj ali za koga'. Tako sem pri izboru "dobrih praks" upoštevala naslednje značilnosti: da posamezni opis nazorno dokumentira proces delovanja in učenje aktivnega državljanstva in s tem služi kot primer za učenje drugih potencialnih aktivnih državljanov; da opis vključuje osebnostno, socialno in politično dimenzijo delovanja in učenja; da je opisana "dobra praksa" učinkovita tako glede vključevanja oziroma sprejetja v družbeno okolje kot tudi glede na kvantitativne (velik krog sodelavcev, učencev idr.) in kvalitativne (inovacija, sprememba idr.) rezultate. Upoštevala sem tudi, da ima "dobra praksa" lastnosti, tipične za slovensko socialno okolje in s tem tudi za obdobje tranzicije.

Aktivno državljanstvo je zdaj nekaj povsem drugega kot pred petnajstimi leti, ko sem začela o tem razmišljati.

Takrat je Urša z majhno skupino študentov, študentk in tudi profesorjev v okviru sekcije Slovenskega društva psihologov prostovoljno sodelovala pri organiziranju predavanj, semi-

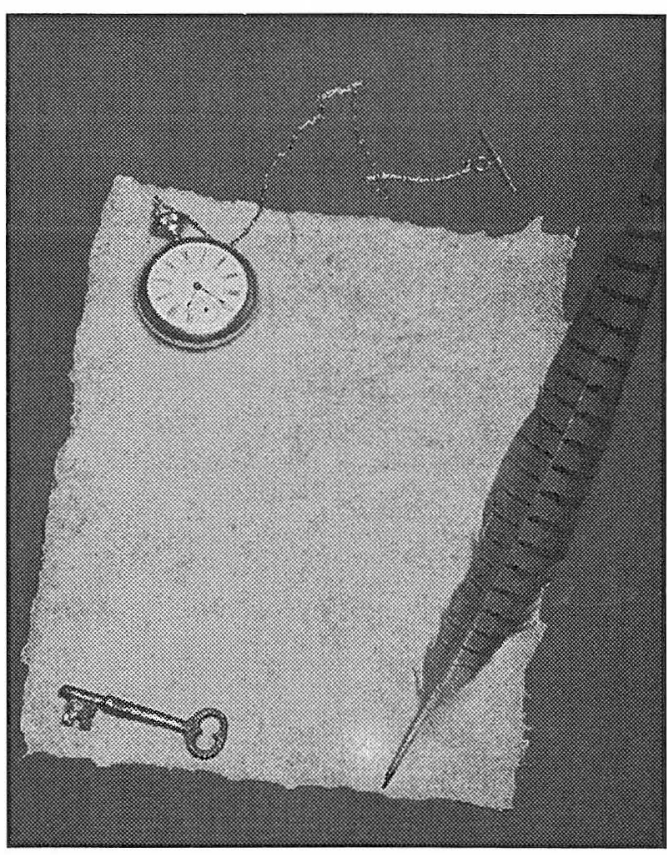

narjev, poletnih šol, obiskov strokovnjakov iz tujine in strokovnih kolegov iz bivše Jugoslavije. S sodelavci in sodelavkami je razmišljala o možnostih uveljavljanja novih idej v praksi, v takrat obstoječih institucijah. Pa tudi o ustanavljanju novih, kot sama pravi, je že takrat razmišljala: o nevladnih organizacijah, s katerimi je imela izkušnje med svojim bivanjem $\mathrm{v}$ tujini. Ker pa tedanje družbeno okolje ni bilo dovzetno za tovrstne inovacije, je še kar nekaj časa delovala $v$ okviru tedaj obstoječih institucij. Na profesionalno strokovnem področju se je zaposlila $\mathrm{v}$ bolnišnici in $\mathrm{s}$ pisanjem strokovnih prispevkov poskušala vplivati na uvajanje alternativnih oblik dela. Sčasoma ji je uspelo, da je bolnišnica uvedla inovacijo, za katero se je zavzemala. Vključila se je $\mathrm{v}$ iniciativo za ustanovitev prve prostovoljne oblike pomoči za osebe v stiskah in aktivno sodelovala $\mathrm{v}$ prvi generaciji prostovoljcev in prostovoljk. Sodelovala je pri ustanovitvi društvene sekcije, ki je razvijala mrežo mentorjev za delo z mladimi. Ko se je obseg mreže in dela povečal, je dala iniciativo za ustanovitev društva za razvijanje preventivnega dela. 
Težave $\mathrm{z}$ ustanavljanjem društva so trajale več let, vse do leta 1991. V okviru novega društva je pridobila več projektov, ki so vključevali prostovoljce in se ukvarjali s pomočjo marginaliziranim in deprivilegiranim manjšinam in skupinam. Ko se je mreža prostovoljcev in dela $\mathrm{z}$ deprivilegiranimi razširila, ji je uspelo združiti prostovoljno, strokovno in profesionalno delovanje. Zaposlila se je kot predsednica društva, ki je počasi preraščalo $\mathrm{v}$ dobro organizirano nevladno organizacijo. $\mathrm{V}$ času eksodusa vojnih beguncev iz Bosne je začela $z$ vzpostavljanjem široke mreže pomoči - v enem tednu so $\mathrm{v}$ društvu zbrali 100 prostovoljcev in prostovoljk za pomoč beguncem v begunskih centrih. Urša se je postopno vključila $\mathrm{v}$ mednarodne povezave in s somišljeniki iz drugih držav organizirala številne akcije pomoči vojnim beguncem na mednarodni ravni. Objavila je prispevke $v$ mednarodnih medijih in sodelovala pri mednarodnem svetovanju za delo $\mathrm{z}$ begunci kot tudi za vodenje nevladnih organizacij. V času intervjuja je izrazila dilemo: videla je potrebo po sodelovanju in povezovanju številnih obstoječih nevladnih organizacij, ustanovljenih med tranzicijo, hkrati pa za tako delovanje še ni videla prave pripravljenosti in objektivnih možnosti. Zato je delovala več $\mathrm{v}$ tujini kot doma. Kljub temu je bila optimistična glede perspektive za svoje delo $\mathrm{v}$ Sloveniji, in sicer $\mathrm{v}$ kontekstu organiziranega sodelovanja med slovenskimi nevladnimi organizacijami.

Aktivni državljani se učijo delovati v skupnosti in za skupnost.

To je vodilo udeleženca M. v ekspertni skupini za področje civilne družbe, mentorja več študijskih krožkov. Ko govori o svoji osebni motivaciji in motivaciji članov/članic krožkov, pravi naslednje: "... jaz si pač vedno želim, in to tudi povem udeležencem krožkov, da vsak na vsakem krožku najde to, kar sam išče, in izživi tisto, kar želi. Dostikrat se izkaže, da se pravzaprav nekateri niti ne zavedajo, da zmorejo izpeljati neko nalogo, da obvladajo neko veščino, ali pa se jim le-ta ne zdi nekaj posebnega. Razvijanje osebnih virov se oblikuje samo, mi (mentorji, op. P. D.) tega ne diktiramo." Udeleženci krožkov izrazijo svoja osebna zanimanja za posamezna področja, potem pa $\mathrm{v}$ sodelovanju in hkratnem učenju uresničujejo izbrane cilje. V okviru enega od krožkov so pred dobrim letom - potem ko so več kot leto dni le modrovali - začeli z urejanjem majhnega kraja. Najprej v maloštevilni skupini krajank in $\mathrm{s}$ premagovanjem številnih zaprek - od težav pri pridobivanju soglasij za ureditev zemljišč, $\mathrm{s}$ prepričevanjem krajevnega župnika, in nesoglasji med samimi udeleženkami krožka. Sledilo je obdobje uglaševanja interesov med člani krožka, kako naj ureditev kraja poteka in izgleda. $\mathrm{Z}$ besedami M.: "... začeli smo s prvo debato, imeli smo dva ali tri krožke, da smo razpravljali in se navajali eden na drugega. Tu sem se jaz bolj ukvarjal s tistim, kar želimo tudi v aktivnem državljanstvu: da daš vsakemu posamezniku možnost, da pove svoje ... Čeprav nisem noben strokovnjak ne za urejanje in ne za rože, sem bil tisti, ki sem povezoval. In smo potem izoblikovali cilj, kaj želimo: uredit škarpo pa živo mejo in nekaj posaditi." $\mathrm{V}$ nadaljevanju so se ukvarjali $\mathrm{z}$ izvedbo cilja: "... začelo se je z izmenjavo znanj, pa tudi z izmenjavo rož." V naslednjem koraku so nabavili potrebno literaturo, šli na skupne oglede vrtnarij, kjer so dobili nekatere potrebščine $\mathrm{v}$ dar. Rezultat teh dejavnosti je bila poleg dobrega razumevanja v skupini tudi ugotovitev, da ne potrebujejo toliko sredstev, kot so sprva predvidevali. Sledilo je delo v dveh skupinah, kot pripoveduje $\mathrm{M}$. Ob delu na terenu so krajanke in tedaj tudi krajani, ki so se v tej fazi pridružili, dobivali nove ideje in širili prvotno zamisel ureditve kraja. Popravilu ograj in zasaditvi 
rož se je pridružila postavitev klopi. Rezultat, o katerem pripoveduje M., je bil večji in pomembnejši od prvotno zastavljenega cilja. Niso le polepšali kraja, pač pa so tudi ustvarili nov javni vaški prostor, na katerem se kra-jani in krajanke redno zbirajo.

\section{LITERATURA}

Giddens, A. (1984). The Constitution of Society. Polity Press.

O'Brien, M. (1998). The Sociology of Anthony Giddens: An Introduction. V A. Giddens and C. Pierson, Conversations with A. Giddens, Making Sense of Modernity. Polity Press.

ETGACE, Analize intervjujev (delovno gradivo), Andragoški center Republike Slovenije.

H. Arendt, Vita activa, str. 78.

${ }^{1}$ Slovenija, Andragoški center Republike Slovenije; UK, University of Surey; Finska, Helsingin yliopisto; Nizozemska, Katholieke Universiteit Nijmegen; Španija, Universitat de Barcelona; Belgija, Katholieke Universiteir Leuven. Več informacij o sodelujočih institucijah in o projektu na naslovu:

http://www.surrey.ac.uk/Education/ETGACE/OLM/ INDEX.HTM

${ }^{2}$ Definicija iz projekta Etgace:

http://www.acs.si/projekti/;

http://www.surrey.ac.uk/Education/ETGACE/

3 ETGACE, Analize intervjujev (delovno gradivo), Andragoški center Republike Slovenije.

${ }^{4}$ Dobra dela pa, ki so produkt tako rekoč dejavne dobrote - tako kot so misli produkt dejavnega mišljenja -, ne morejo biti nikdar sestavni del sveta. (Arendt, Vita activa, str. 78) 